\title{
Retinal vasoproliferative tumour-induced intractable neovascular glaucoma in a child with neurofibromatosis type 1
}

\author{
Deepika C Parameswarappa, ${ }^{1}$ Abhilasha Arvind Alone, ${ }^{2}$ Padmaja Kumari Rani ${ }^{1}{ }^{1}$
}

${ }^{1}$ Vitreo-retina, LV Prasad Eye Institute, Hyderabad, India ${ }^{2}$ Retina, LV Prasad Eye Institute, Hyderabad, India

\section{Correspondence to} Dr Padmaja Kumari Rani; rpk111@gmail.com

Accepted 15 July 2020
Check for updates

(c) BMJ Publishing Group Limited 2020. No commercial re-use. See rights and permissions. Published by BMJ.

To cite:
C Parameswarappa D,
Alone AA, Rani PK. BMJ
Case Rep 2020;13:e237305.
doi:10.1136/bcr-2020-
237305

\section{DESCRIPTION}

A 14-year-old boy presented with pain in the left eye over the past 1 week. His best-corrected visual acuity was 20/20 and 20/50 in the right and left eyes, respectively. On anterior segment examination, the iris in both eyes had pigmented nodular lesions on their surfaces. The left eye had florid neovascularisation of the iris at the pupillary margin and ectropion uveae, closed angles with raised intraocular pressure of $39 \mathrm{~mm} \mathrm{Hg}$ (figure 1A,B). The left eye's retina had a yellowish intraretinal elevated mass lesion in the inferior quadrant with dilated and tortuous vessels overlying the surface with subretinal and intraretinal exudations (figure 2A). The right eye's examination yielded unremarkable results. The ultrasound examination of the left eye revealed a medium echogenic retinal mass lesion without calcification (figure 2B). The iris nodules led us to conduct a systemic examination which revealed multiple flat pigmented lesions over the forearm and abdomen, characteristic of cafe-au-lait spots (figure 1C,D), and thus the pigmented nodules over the iris were indicative of Lisch nodules. Based on the previous clinical presentation, a diagnosis of neurofibromatosis type $1^{1}$ with neovascular glaucoma secondary to retinal vasoproliferative tumour (RVPT) was made in the left eye. The left eye was treated with maximum medical management for glaucoma initially, followed by trabeculectomy and glaucoma valve implant. The RVPT was treated with plaque brachytherapy. Despite all these measures, the disease's course was intractable and the visual acuity was 20/500 at the end. Simultaneous systemic examination of the patient and family screening were also carried out.

Neurofibromatosis 1 (NF1) is a multisystem neurocutaneous disorder with bony and ocular involvement. NF1 is most often autosomal dominant in nature with its defective gene being neurofibromin on chromosome $17 \mathrm{q} 11 .{ }^{1}$ The role of the ophthalmologist is vital in view of NF1's ocular manifestations, which include palpebral neurofibromas, Lisch nodules of the iris, glaucoma, optic nerve glioma, strabismus and proptosis. ${ }^{2-4}$

RVPT is a proliferative vascular tumour characterised by red to pink or dirty yellow vascular retinal mass lesions seen in the inferior or inferotemporal quadrant associated with feeder vessels, retinal telangiectasia, subretinal exudates, macular oedema and epiretinal membrane. ${ }^{5-7}$ RVPTs can be primary and idiopathic or secondary to ocular and

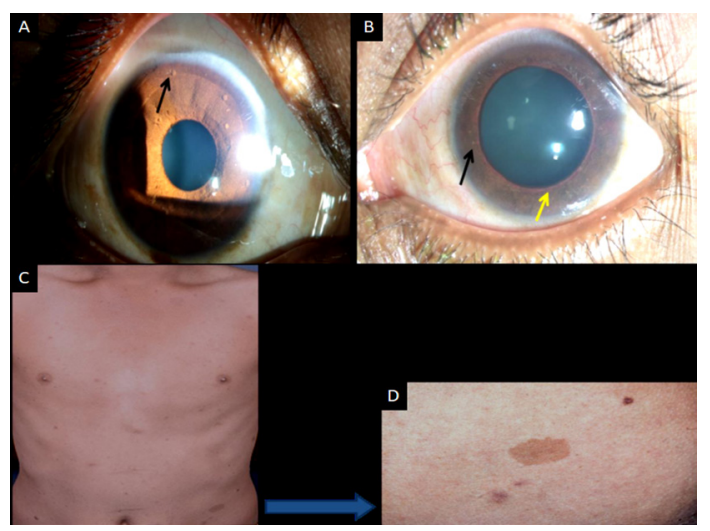

Figure 1 Both eyes iris surface showed pigmented nodular lesion (black arrows) suggestive of Lisch nodules. $(A, B)$ Left eye $(B)$ showed florid neovascularisation at the papillary margin and ectropion uveae (yellow arrow). Clinical photograph (C) showing upper chest and abdomen with multiple flat pigmented lesions characteristic of cafe-au-lait spots. (D) Magnified view.

systemic anomalies. Secondary RVPT can be seen in cases of retinopathy of prematurity, familial exudative vitreoretinopathy, Coats' disease, chronic retinal detachment, uveitis conditions, prior laser photocoagulation or cryotherapy and neurofibromatosis type I (such as in our case)..$^{5-7}$ RVPT resulting in glaucoma has been reported previously. $^{89}$ The treatment is mainly aimed at treating the RVPT with parallel management of glaucoma. Treatment options available for RVPT are laser photocoagulation, transpupillary

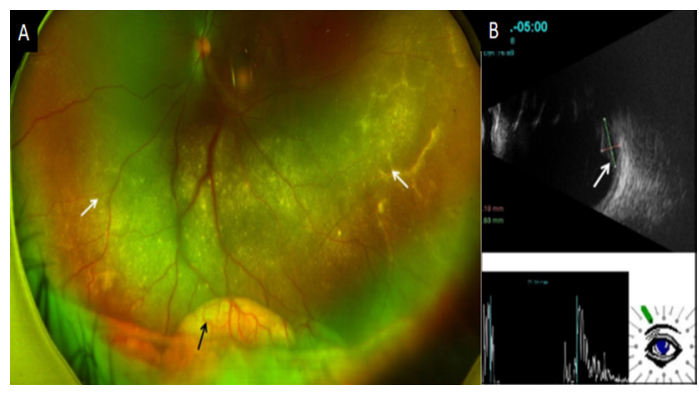

Figure 2 Left eye fundus (A) showed an intreretinal elevated mass lesion in the inferior quadrant with dilated and tortuous vessels overlying the surface (black arrow) with subretinal and intraretinal exudations (white arrows). Ultrasound B-scan examination of the left eye (B) showed a medium echogenic retinal mass lesion (white arrow) with no calcification. 
thermotherapy, cryotherapy, plaque brachytherapy, intravitreal triamcinolone or antivascular endothelial growth factor, and vitreoretinal surgery.

\section{Learning points}

- The association of secondary retinal vasoproliferative tumour (RVPT) with NF 1 and possibilities of its presentation as neovascular glaucoma are to be kept in mind.

- The primary therapy for RVPT leading to neovascular glaucoma should be aimed at treating the RVPT lesion and the parallel management of glaucoma.

Contributors Data collection, writing and processing: DCP and AAA; writing, editing and processing: PKR.

Funding The authors have not declared a specific grant for this research from any funding agency in the public, commercial or not-for-profit sectors.

Competing interests None declared.

Patient consent for publication Obtained.

Provenance and peer review Not commissioned; externally peer reviewed.
ORCID iD

Padmaja Kumari Rani http://orcid.org/0000-0001-7069-8238

\section{REFERENCES}

1 National Institutes of Health Consensus Development Conference Statement. Neurofibromatosis. Arch Neurol 1988:45:575-8.

2 Ferner RE, Huson SM, Thomas N, et al. Guidelines for the diagnosis and management of individuals with neurofibromatosis 1. J Med Genet 2007;44:81-8.

3 Abdolrahimzadeh B, Piraino DC, Albanese G, et al. Neurofibromatosis: an update of ophthalmic characteristics and applications of optical coherence tomography. Clin Ophthalmol 2016;10:851.

4 Kinori M, Hodgson N, Zeid JL. Ophthalmic manifestations in neurofibromatosis type 1. Surv Ophthalmol 2018:63:518-33.

5 Shields CL, Kaliki S, Al-Dahmash S, et al. Retinal vasoproliferative tumors: comparative clinical features of primary vs secondary tumors in 334 cases. JAMA Ophthalmol 2013:131:328-34.

6 Shields CL, Shields JA, Barrett J, et al. Vasoproliferative tumors of the ocular fundus. classification and clinical manifestations in 103 patients. Arch Ophthalmol 1995;113:615-23.

7 Honavar SG. Retinal vasoproliferative tumor - A proposal for classification. Indian J Ophthalmol 2018;66:185.

8 Jain K, Berger AR, Yucil YH, et al. Vasoproliferative tumours of the retina. Eye 2003;17:364-8.

9 Nakamura Y, Takeda N, Mochizuki M. A case of vasoproliferative retinal tumor complicated by neovascular glaucoma. Retin Cases Brief Rep 2013;7:338-42.

Copyright 2020 BMJ Publishing Group. All rights reserved. For permission to reuse any of this content visit

https://www.bmj.com/company/products-services/rights-and-licensing/permissions/

BMJ Case Report Fellows may re-use this article for personal use and teaching without any further permission.

Become a Fellow of BMJ Case Reports today and you can:

- Submit as many cases as you like

Enjoy fast sympathetic peer review and rapid publication of accepted articles

- Access all the published articles

- Re-use any of the published material for personal use and teaching without further permission

Customer Service

If you have any further queries about your subscription, please contact our customer services team on +44 (0) 2071111105 or via email at support@bmj.com.

Visit casereports.bmj.com for more articles like this and to become a Fellow 